AT - TADBIR

JURNAL ILMIAH MANAJEMEN

Homepage: ojs.uniska.ac.id/attadbir

\title{
Reaksi Pasar Modal Indonesia Sebelum dan Sesudah Pengumuman Paket Kebijakan Ekonomi XVI pada Saham Sektor Pertambangan yang Terdaftar Di Bursa Efek Indonesia Tahun 2018
}

\author{
Erni Alfisah \\ Fakultas Ekonomi, Universitas Islam Kalimantan \\ J1. Adhyaksa No. 2, Kayutangi, Banjarmasin \\ e-mail: alfisaherni@yahoo.co.id
}

\begin{abstract}
This research is aimed to analyze and understand the difference in the average abnormal return (AAR) and the average trading volume activity (ATVA) with several periods of observation both before or after the announcement of the economic policy package XVI in the mining sector included on the Stock Exchange in 2018 is the research objective. Event study is a type of research used. The announcement of the economic policy package XVI is a test event. The study requires secondary data which includes data on daily closing price, trading volume, and the number of shares outstanding from the mining sector samples being sampled. After the paired samples t-test was tested differently it was stated that there were no differences in observations 5 days \& 10 days before and 5 days \& 10 days after the announcement of the economic policy package XVI, at ATVA 10 days before \& 10 days after the economic policy package XVI was found differences ATVA.
\end{abstract}

Keywords: AAR (average abnormal return), ATVA (average trading volume activity), Announcement of Economic Policy Package XVI 2018, event studies.

\begin{abstract}
Abstrak
Penelitian ini bertujuan untuk mengetahui dan menganalisis perbedaan rata-rata abnormal return (AAR) dan rata-rata trading volume activity (ATVA) dengan beberapa periode pengamatan baik sebelum atau setelah diumumkan paket kebijakan ekonomi XVI pada sektor pertambangan yang termasuk di BEI ditahun 2018 merupakan tujuan penelitian. Event study merupakan jenis penelitian yang digunakan. Pengumuman paket kebijakan ekonomi XVI merupakan peristiwa yang di uji.. Penelitian memerlukan data sekunder yang meliputi data harga penutupan saham harian, volume perdagangan, dan jumlah saham yang beredar dari saham sektor pertambangan yang menjadi sampel. Setelah dilakukan uji beda paired samples t-test dinyatakan tidak terdapat perbedaan pada pengamatan 5 hari \& 10 hari sebelum dan 5 hari \& 10 hari setelah diumumkan paket kebijakan ekonomi XVI, pada ATVA 10 hari sebelum \& 10 hari setelah diumumkan paket kebijakan ekonomi XVI ditemukan perbedaan ATVA.
\end{abstract}

Kata Kunci : AAR (rata-rata abnormal return), ATVA (rata-rata trading volume activity), Pengumuman Paket Kebijakan Ekonomi XVI tahun 2018, studi peristiwa. 


\section{PENDAHULUAN}

Saat ini investasi sudah menjadi istilah yang umum bagi masyarakat, orang yang melakukan investasi disebut dengan investor. Orang yang melakukan investasi disebut dengan investor. Investasi bisa dilakukan dengan berbagai macam pilihan. Salah satu investasi yang bisa dilakukan oleh investor yaitu berinvestasi dalam bentuk aset keuangan, yaitu investasi melalui pasar modal atau biasa disebut dengan bursa efek atau pasar modal. Pasar modal merupakan tempat bertemunya para pemilik modal dan pencari modal, keinginan dari para pemilik modal yakni mendapatkan keuntungan dari investasi yang dilakukan (Tanderlilin, 2010:26). Pasar modal berfungsi sebagai lembaga perantara.

Saat ini, pasar sangat merespon cepat setiap informasi baik yang berhubungan langsung dengan lingkungan ekonomi maupun lingkungan non ekonomi. Bentuk informasi yang dapat mempengaruhi perubahan harga saham di pasar modal merupakan bentuk dari suatu peristiwa (event). Menurut Hartono (2018:36-39) berdasarkan tipe, peristiwa itu terbagi menjadi dua, yaitu peristiwa pengumuman dan peristiwa kejadian. Peristiwa yang ingin diteliti kandungan informasinya dalam penelitian ini adalah berbentuk pengumuman yakni pengumuman paket kebijakan ekonomi XVI yang dilakukan oleh Menteri Koordinator Bidang Perekonomian Darmin Nasution.

Dikutip dari situs www.suara.com, paket kebijakan ekonomi XVI dikeluarkan untuk mengurangi dampak pelemahan ekonomi global yang saat ini terjadi, pertumbuhan ekonomi global pada tahun 2019 yang diprediksi masih akan melambat, kebijakan normalisasi moneter di Amerika yang masih akan berlanjut, munculnya potensi perang dagang Amerika Serikat dengan negara lain, dan komoditi utama di pasar dunia serta volatilitas harga minyak yang masih tinggi.

Dari gambar 1 dapat dilihat terjadi fluktuasi pada Indeks Harga Saham Gabungan (IHSG) dan indeks pertambangan. Berdasarkan data dari www.idx.co.id pada perdagangan hari Senin (19/11/2018), Indeks Harga Saham Gabungan (IHSG) ditutup 6.005,30 atau melemah -7,05, sedangkan penutupan sehari sebelumnya yaitu pada hari Jum'at (16/11/2018) adalah 6.012,35. Pada Indeks Pertambangan dihari perdagangan Senin (19/11/2018) ditutup 1844,93 atau melemah $-1 \%$, sedangkan penutupan pada hari perdagangan sebelumnya yaitu Jum'at (16/11/2018) adalah 1863.93. Dapat dilihat terjadi perubahan penutupan pada Indeks Harga Saham Gabungan (IHSG) dan Indeks Pertambangan setelah kebijakan tersebut diumumkan. Jika pengumuman mengandung informasi yang dapat diterima oleh para pelaku pasar, maka diharapkan pasar akan bereaksi yang ditunjukan dengan adanya perubahan harga saham. Pengujian kandungan informasi dalam penelitian ini dimaksudkan untuk melihat reaksi dari suatu pengumuman.

Peneliti berupaya melakukan event study mengenai kaitannya dengan abnormal return dan trading volume acivity pada peristiwa pengumuman paket kebijakan ekonomi XVI. Periode pengamatan yang dilakukan dalam penelitian yaitu selama 20 hari (meliputi 10 hari sebelum dan 10 hari sesudah peristiwa). 


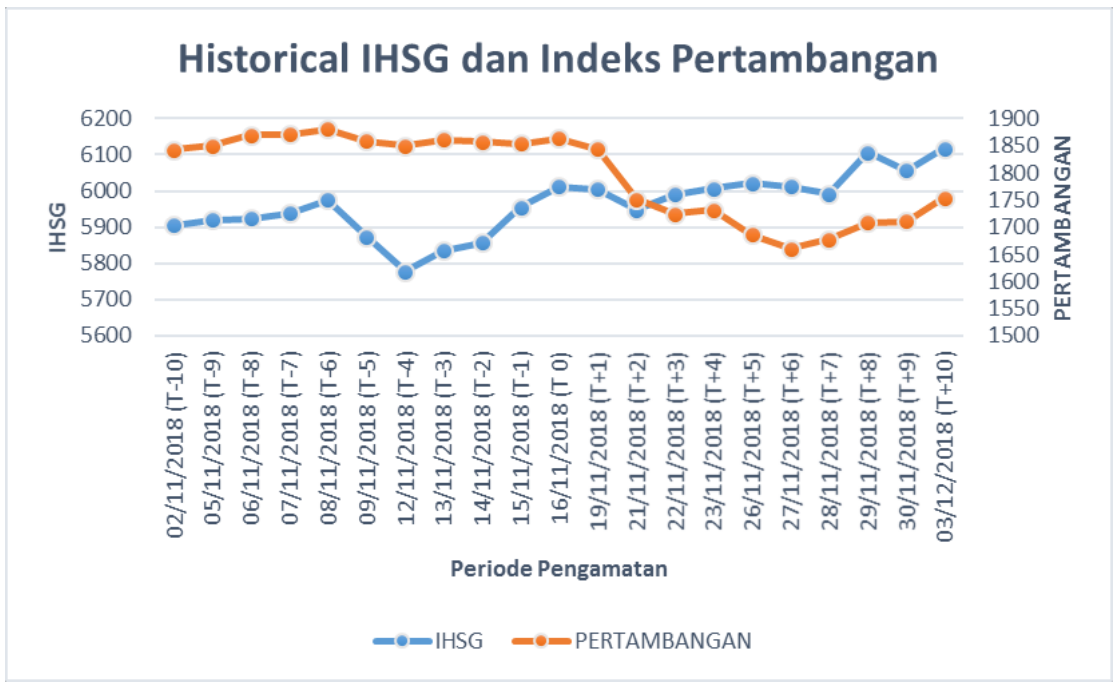

Gambar 1. Fluktuasi Harga saham

\section{KAJIAN PUSTAKA}

\section{Pasar Modal}

Terjadinya aktivitas penjualan \& pembelian sekuritas serta perjumpaan oleh pihak yang memiliki dana berlebih dengan pihak yang membutuhkan pendanaan. Dalam menunjang perekonomian, pasar modal berperan penting dan berfungsi sebagai lembaga perantara. (Tanderlilin, 2010, p.26).

\section{Efisiensi Pasar}

Jika harga semua sekuritas yang melakukan perdagangan dapat memperlihatkan semua informasi yang ada maka merupakan pasar modal efisien, apabila efisien maka disebut pasar modal baik (Tanderlilin, 2010, p.219). Ada berbagai macam bentuk efisiensi pasar salah satunya efisiensi pasar secara informasi, efisiensi tersebut diklarifikasi menjadi tiga efficien market hyphotesis $(\mathrm{EMH})$ dan dilakukan penyempurnaan, studi persitiwa merupakan perubahan dari efisiensi pasar bentuk setengah kuat (Tanderlilin, 2010, p.224).

\section{Studi Peristiwa}

Suatu pendekatan metodologikal yang dikategorikan penting serta dipergunakan untuk kepentingan penelitian. Metode ini dapat dipergunakan untuk melakukan pengujian suatu reaksi pasar akibat suatu pengumuman (Hartono, 2017, p.643).

\section{Return}

Sebuah aktivitas investasi yang memperoleh hasil disebut return. Bentuk return bisa berupa return realisasian (sudah terjadi) dan return ekspektasian (belum terjadi) akan tetapi return ini diharapkan terjadi dimasa akan datang (Hartono, 2017, p.283).

Return Ekspektasi (Expected Return)

Dapat dipergunakan untuk pengambilan keputusan investasi merupakan Return ekspektasi. Return ini termasuk penting dibanding dengan return lain karena diharapkan dari sebuah investasi (Hartono, 2017, p.300).

Untuk mengestimasi return ekspektasi, Hartono (2017, p.668-679) mengemukakan model yang dikemukakan oleh Bowo dan warner (1985) yakni :

1. Mean-adjusted model, beranggapan yakni rata-rata return realisasian selama periode bernilai sama dengan estimasi return ekspektasian.

2. Market model, membentuk model ekspektasi, diberlakukan atas dua tahapan, yaitu (1)model ekspektasi yang terbentuk dimanfaatkan untuk 
memperikarakan return ekspektasian pada periode jendela, dan (2)data realisasi dalam periode estimasi dibentuk model ekspektasi.

3. Market-adjusted model, model ini berasumsi return indeks pasar pada saat tersebut merupakan penduga yang terbaik dalam mengestimasi return.

Return tak normal atau Abnormal return (AR).

Menurut Hartono (2017, p.667), return berlebihan yang sesungguhnya terjadi terhadap return yang normal yakni abnormal return. Kelebihan hasil yang diinginkan oleh pemodal ataupun hasil lebih return ekspektasian merupakan kelebihan yang normal.

Aktivitas Volume Perdagangan atau Trading Volume Activity (TVA)

Wardani (2004) dalam Maharani (2018) mengutarakan, reaksi pasar dapat ditinjau dengan menerapkan parameter pergerakan TVA. Peristiwa dikatakan berita baik (good news) jika volume mengalami peningkatan karena permintaan, dikatakan berita buruk (bad news) jika terjadi peningkatan karena penjualan.

Paket Kebijakan Ekonomi Enam Belas (XVI)

Kebijakan yang terbit diminggu ke-III bulan November 2018 atau tanggal 16 November 2018 merupakan kebijakan terbaru oleh pemerintah Indonesia yaitu Paket kebijakan ekonomi XVI atau PKE XVI. Dikutip dari situs www.setkab.go.id kebijakan ini diterbitkan karena pertumbuhan ekonomi Indonesia tahun 2019 diprediksi mengalami perlambatan, kebijakan normalisasi moneter oleh Amerika, terjadi perang dagang negara lain dengan US, dan dipasar dunia komoditi utama dan volatilitas harga masih tinggi.sehingga menyebabkan ekonomi global mengalami ketidakpastian.

\section{METODE PENELITIAN}

Jenis Penelitian

Bentuk penelitian yang digunakan dalam penelitian inin adalah metode studi peristiwa. Studi peristiwa digunakan menguji reaksi pasar dari suatu peristiwa atau pengumuman yang dikeluarkan oleh pihak badan yang bersangkutan.

\section{Jenis data dan sampel}

Jenis data yang digunakan yaitu data sekunder berupa harga penutupan (close price) saham harian, volume perdagangan, dan jumlah saham yang beredar (listed share) pada saham sektor pertambangan yang terdaftar di Bursa Efek Indonesia tahun 2018.

\section{Analisis Data}

Teknik analisis data dalam penelitian ini menggunakan perhitungan abnormal return dan trading volume activity dengan alat bantu software Microsoft Excel 2016. Model pengujian yang digunakan dalam penelitian ini adalah model Uji beda rata-rata (paired sample t-test) dan Wilcoxon signed rank test.

\section{HASIL DAN PEMBAHASAN}

Hasil

Data AAR dan ATVA 5 dan 10 hari sebelum peristiwa serta 5 dan 10 hari setelah peristiwa. 13 perusahaan sektor pertanian yang menjadi sampel penelitian dibutuhkan dalam penelitian. Mengetahui dan menelaah perbedaan dari AAR dan ATVA setelah ataupun sebelum pengumuman PKE VXI dengan beberapa periode pengamatan merupakan tujuan dari penelitian.

\section{Analisis Desktiptif}

Statistik Deskriptif Rata-rata Abnormal Return (AR)

Statistik Deskriptif dari AAR setelah dan sebelum pengumuman paket kebijakan ekonomi XVI pada tahun 2018, disajikan pada tabel 1. 
Tabel 1. Statistik Deskriptif Rata-rata Abnormal Return Seluruh Periode

\begin{tabular}{|l|c|r|r|r|r|}
\hline & $\mathbf{N}$ & \multicolumn{1}{c|}{ Mean } & Std. Deviasi & Minimum & Maksimum \\
\hline AAR Sebelum & 5 & -0.000918 & 0.0055363 & -0.00736 & 0.00642 \\
\hline AAR Sesudah & 5 & -0.006754 & 0.0013003 & -0.00857 & -0.00492 \\
\hline AAR Sebelum & 10 & -0.000299 & 0.0093525 & -0.01889 & 0.01256 \\
\hline AAR Sesudah & 10 & -0.00693 & 0.0095927 & -0.02152 & 0.0121 \\
\hline
\end{tabular}

Sumber: Data diolah, 2020

Berdasarkan tabel 1, dapat dilihat rata-rata abnormal return periode 5 hari sebelum pengumuman memiliki rata-rata abnormal return sebelum terendah atau minimum sebesar -0,00736 terjadi pada periode T-5 yaitu pada tanggal 9 November 2018, artinya terdapat rata-rata abnormal return negatif sebesar $-0,736 \%$. Rata-rata abnormal return 5 hari sebelum peristiwa tertinggi sebesar 0,00642 terjadi pada periode pengamatan T4 yaitu pada tanggal 12 November 2018, artinya terdapat rata-rata abnormal return positif sebesar $0,642 \%$. Nilai mean sebelum peristiwa yaitu -0.000918 dengan standar deviasi 0.0055363 . Kemudian, pada periode 5 hari sesudah peristiwa pengumuman, ratarata abnormal return terendah yaitu -0.00857 terjadi pada periode $\mathrm{T}+3$ yaitu pada tanggal 22 November 2018, artinya terdapat rata-rata abnormal return negatif sebesar $-0,857 \%$. Rata-rata abnormal return tertinggi 5 hari sesudah peristiwa sebesar -0.00492 terjadi pada periode pengamatan $\mathrm{T}+4$ yaitu pada tanggal 23 November 2018, artinya terdapat rata-rata abnormal return positif sebesar 0,492\%. Nilai mean dari periode sesudah peristiwa yaitu -0.006754 dengan standar deviasi 0.0013003 .

Rata-rata abnormal return periode 10 hari sebelum pengumuman memiliki rata-rata abnormal return sebelum terendah atau minimum sebesar $-0,01889$ terjadi pada periode T-10 yaitu pada tanggal 2 November
2018, artinya terdapat rata-rata abnormal return atau return tak normal negatif sebesar $-1,889 \%$. Rata-rata abnormal return sebelum peristiwa tertinggi sebesar 0,01256 terjadi pada periode pengamatan T-8 yaitu pada tanggal 6 November 2018, artinya terdapat rata-rata abnormal return positif sebesar $1,256 \%$. Nilai mean sebelum peristiwa yaitu $-0,0002990$ dengan standar deviasi 0,00935254 . Kemudian, pada periode 10 hari sesudah peristiwa pengumuman, rata-rata abnormal return terendah yaitu $-0,02152$ terjadi pada periode $\mathrm{T}+8$ yaitu pada tanggal 29 November 2018, artinya terdapat rata-rata abnormal return atau return tak normal negatif sebesar $-2,152 \%$. Rata-rata abnormal return tertinggi 10 hari sesudah peristiwa sebesar 0,01210 terjadi pada periode pengamatan $\mathrm{T}+7$ yaitu pada tanggal 28 November 2018, artinya terdapat rata-rata abnormal return positif sebesar $1,210 \%$. Nilai mean dari periode sesudah peristiwa yaitu 0,0069300 dengan standar deviasi 0,00959274 .

\section{Statistik deskriptif Rata-rata Trading Volume Activity (TVA) \\ Statistik Deskriptif dari rata-rata trading volume activity sebelum dan sesudah pengumuman paket kebijakan ekonomi XVI pada tahun 2018, dapat dilihat pada tabel berikut :}


Tabel 2. Statistik Deskriptif Rata-rata Trading Volume Activity Seluruh Periode

\begin{tabular}{|l|c|c|r|r|r|}
\hline & N & Mean & Std. Deviasi & \multicolumn{1}{c|}{ Minimum } & Maksimum \\
\hline ATVA Sebelum & 5 & 0.0013186 & 0.0002501 & 0.001009 & 0.001687 \\
\hline ATVA Sesudah & 5 & 0.0020646 & 0.000555 & 0.001303 & 0.002679 \\
\hline ATVA Sebelum & 10 & 0.0013713 & 0.0002908 & 0.00097 & 0.001911 \\
\hline ATVA Sesudah & 10 & 0.0020816 & 0.0006301 & 0.001303 & 0.003446 \\
\hline
\end{tabular}

Sumber: Data diolah, 2020

Berdasarkan tabel 2, dapat dilihat ratarata trading volume activity periode 5 hari sebelum pengumuman paket kebijakan ekonomi XVI memiliki rata-rata trading volume activity sebelum terendah atau minimum sebesar 0.001009 terjadi pada periode T-4 yaitu pada tanggal 12 November 2018, artinya terdapat rata-rata trading volume activity positif sebesar $0,1009 \%$. Rata-rata trading volume activity tertinggi 5 hari sebelum peristiwa sebesar sebesar 0.001687 terjadi pada periode pengamatan T2 yaitu pada tanggal 14 November 2018, artinya terdapat rata-rata trading volume activity positif sebesar $0,1687 \%$. Nilai mean dari rata-rata trading volume activity periode sebelum peristiwa yaitu 0.0013186 dengan standar deviasi 0.0002501. Kemudian, pada periode 5 hari sesudah peristiwa pengumuman paket kebijakan ekonomi XVI, nilai minimum rata-rata trading volume activity yaitu 0,001303 terjadi pada periode $\mathrm{T}+1$ yaitu pada tanggal 19 November 2018, artinya terdapat rata-rata trading volume activity positif sebesar $0,1303 \%$. Rata-rata trading volume activity tertinggi 5 hari sesudah peristiwa sebesar 0.002679 terjadi pada periode pengamatan $\mathrm{T}+2$ yaitu pada tanggal 21 November 2018, artinya terdapat rata-rata trading volume activity positif sebesar $0,2679 \%$. Nilai mean dari rata-rata trading volume activity periode sesudah peristiwa yaitu 0.0020646 dengan standar deviasi 0.000555 .

Rata-rata trading volume activity periode 10 hari sebelum pengumuman paket kebijakan ekonomi XVI memiliki rata-rata trading volume activity sebelum terendah atau minimum sebesar 0,000977 terjadi pada periode T-10 yaitu pada tanggal 2 November 2018, artinya terdapat rata-rata trading volume activity positif sebesar 0,0977\%. Rata-rata trading volume activity tertinggi 10 hari sebelum peristiwa sebesar 0,001911 terjadi pada periode pengamatan T-6 yaitu pada tanggal 8 November 2018, artinya terdapat rata-rata trading volume activity positif sebesar $1,911 \%$. Nilai mean dari ratarata trading volume activity periode sebelum peristiwa yaitu 0,00137130 dengan standar deviasi 0,000290849. Kemudian, pada periode 10 hari sesudah peristiwa pengumuman paket kebijakan ekonomi XVI, nilai minimum rata-rata trading volume activity yaitu 0,001303 terjadi pada periode $\mathrm{T}+1$ yaitu pada tanggal 19 November 2018, artinya terdapat rata-rata trading volume activity positif sebesar $0,1303 \%$. Rata-rata trading volume activity tertinggi 10 hari sesudah peristiwa sebesar 0,003446 terjadi pada periode pengamatan $\mathrm{T}+9$ yaitu pada tanggal 30 November 2018, artinya terdapat rata-rata trading volume activity positif sebesar $0,3446 \%$. Nilai mean dari rata-rata trading volume activity periode sesudah peristiwa yaitu 0,00208160 dengan standar deviasi 0,000630082 .

\section{Uji Normalitas}

\section{Uji Normalitas AAR}

Pengujian normalitas untuk AAR sebelum dan sesudah pengumuman paket kebijakan ekonomi XVI pada tahun 2018, dapat dilihat pada tabel 3: 
Tabel 3. Hasil Uji Normalitas Rata-rata Abnormal Return

\begin{tabular}{|l|l|l|l|}
\hline & AAR Sebelum & AAR Sesudah & Keterangan \\
\hline $\mathrm{N}$ & 5 & 5 & \\
\hline Asymp.Sig. (2-tailed) & 0,200 & 0,200 & Normal \\
\hline $\mathrm{N}$ & 10 & 10 & \\
\hline Asymp.Sig. (2-tailed) & 0,200 & 0,135 & Normal \\
\hline
\end{tabular}

Sumber: Data diolah, 2020

Tabel 4. Hasil Uji Normalitas Rata-rata Trading Volume Activity

\begin{tabular}{|l|l|l|l|}
\hline & ATVA Sebelum & ATVA Sesudah & Keterangan \\
\hline $\mathrm{N}$ & 5 & 5 & \\
\hline Asymp.Sig. (2-tailed) & 0,200 & 0,200 & Normal \\
\hline $\mathrm{N}$ & 10 & 10 & \\
\hline Asymp.Sig. (2-tailed) & 0,200 & 0,200 & Normal \\
\hline
\end{tabular}

Sumber: Data diolah, 2020

Pada tabel 3, periode pengamatan 10 hari (5 hari sebelum dan 5 hari sesudah) dapat dilihat dengan jumlah $\mathrm{N}$ berdasarkan lamanya periode pengamatan yaitu 20 hari. Hasil Asymp.Sig (2-tailed) atau $\mathrm{P}$-value rata-rata abnormal return sebelum sebesar 0,200 lebih dari 0,05 dan Asymp.Sig (2-tailed) atau Pvalue rata-rata abnormal return setelah sebesar 0,200 lebih dari 0,05, sehingga dapat disimpulkan data rata-rata abnormal return terdistribusi secara normal.

Pada periode pengamatan 20 hari (10 hari sebelum dan 10 hari sesudah) dapat dilihat dengan jumlah $\mathrm{N}$ berdasarkan lamanya periode pengamatan yaitu 20 hari. Hasil Asymp.Sig (2-tailed) atau P-value rata-rata abnormal return sebelum sebesar 0,200 lebih dari 0,05 dan Asymp.Sig (2-tailed) atau Pvalue rata-rata abnormal return setelah sebesar 0,135 lebih dari 0,05, sehingga dapat disimpulkan data rata-rata abnormal return terdistribusi secara normal.

\section{Uji Normalitas ATVA}

Pengujian normalitas ATVA sebelum dan sesudah pengumuman paket kebijakan ekonomi XVI pada tahun 2018 dapat dilihat pada tabel 4 .
Pada tabel 4, periode pengamatan 10 hari (5 hari sebelum dan 5 hari sesudah) dan 20 hari (10 hari sebelum dan 10 hari sesudah ) dapat dilihat dengan jumlah $\mathrm{N}$ berdasarkan lamanya periode pengamatan yaitu 20 hari. Hasil Asymp.Sig (2-tailed) atau P-value ratarata trading volume activity sebelum sebesar 0,200 lebih dari 0,05 dan Asymp.Sig (2tailed) atau $\mathrm{P}$-value rata-rata trading volume activity setelah sebesar 0,200 lebih dari 0,05, sehingga dapat disimpulkan data rata-rata trading volume activity semua periode pengamatan terdistribusi secara normal.

\section{Uji Hipotesis}

Semua data terdistribusi normal maka semua uji hipotesis menggunakan uji beda Paired Samples T-tes. Dalam pengujian hipotesis ini terdapat empat pengujian hipotesis yang dapat ditunjukkan sebagai berikut.

\section{Hipotesis Pertama}

Pengujian hipotesis pertama dilakukan untuk mengetahui ada atau tidaknya perbedaan antara rata-rata abnormal return 5 hari sebelum dan rata-rata abnormal return 5 hari sesudah pengumuman paket kebijakan ekonomi XVI pada tahun 2018 yang 
ditunjukkan pada tabel 5 .

Berdasarkan tabel 5 , pengujian rata-rata abnormal return dengan tingkat signifikasi $\alpha=5 \%$ atau 0,05 , menunjukan nilai $P$ Value Sig. (2-tailed) yaitu $0,072>0,05$ sehingga tidak terdapat perbedaan, maka hipotesis pertama ditolak yang berarti tidak terdapat perbedaan rata-rata abnormal return 5 hari sebelum dan 5 hari sesudah pengumuman paket kebijakan ekonomi XVI pada saham sektor pertambangan yang terdaftar di Bursa Efek Indonesia tahun 2018.

Tabel 5. Hasil Uji Paired Samples t-test pada Hipotesis Pertama

\begin{tabular}{|l|c|c|}
\hline \multicolumn{3}{|c|}{ Periode Pengamatan 10 Hari (5 Hari Sebelum dan 5 Hari Sesudah) } \\
\hline & Asymp.Sig. (2-tailed) & Keterangan \\
\hline AAR Sebelum - AAR Sesudah & 0,072 & Tidak Terdapat Perbedaan \\
\hline
\end{tabular}

Sumber: Data diolah, 2020

Tabel 6. Hasil Uji Paired Samples t-test pada Hipotesis Kedua

\begin{tabular}{|l|c|c|}
\hline \multicolumn{3}{|c|}{ Periode Pengamatan 20 Hari (10 Hari Sebelum dan 10 Hari Sesudah) } \\
\hline & Asymp.Sig. (2-tailed) & Keterangan \\
\hline AAR Sebelum - AAR Sesudah & 0,125 & Tidak Terdapat Perbedaan \\
\hline
\end{tabular}

Sumber: Data diolah, 2020

Tabel 7. Hasil Uji Paired Samples t-test pada Hipotesis Ketiga

\begin{tabular}{|c|c|c|}
\hline \multicolumn{3}{|c|}{ Periode Pengamatan 10 Hari (5 Hari Sebelum dan 5 Hari Sesudah) } \\
\hline & Asymp.Sig. (2-tailed) & Keterangan \\
\hline ATVA Sebelum - ATVA Sesudah & 0,075 & Tidak Terdapat Perbedaan \\
\hline
\end{tabular}

Sumber: Data diolah, 2020

Tabel 8. Hasil Uji Paired Samples t-test pada Hipotesis Keempat

\begin{tabular}{|c|c|c|}
\hline \multicolumn{3}{|c|}{ Periode Pengamatan 20 Hari (10 Hari Sebelum dan 10 Hari Sesudah) } \\
\hline & Asymp.Sig. (2-tailed) & Keterangan \\
\hline ATVA Sebelum - ATVA Sesudah & 0,001 & Terdapat Perbedaan \\
\hline
\end{tabular}

Sumber: Data diolah, 2020

\section{Hipotesis Kedua}

Pengujian hipotesis kedua dilakukan untuk mengetahui ada atau tidaknya perbedaan antara rata-rata abnormal return 10 hari sebelum dan rata-rata abnormal return 10 hari sesudah pengumuman paket kebijakan ekonomi XVI pada tahun 20182018 dapat dilihat pada tabel 6 .

Pada tabel 6, periode pengamatan 10 hari (5 hari sebelum dan 5 hari sesudah) dan 20 hari (10 hari sebelum dan 10 hari sesudah ) dapat dilihat dengan jumlah $\mathrm{N}$ berdasarkan lamanya periode pengamatan yaitu 20 hari. Hasil Asymp.Sig (2-tailed) atau P-value ratarata trading volume activity sebelum sebesar 0,200 lebih dari 0,05 dan Asymp.Sig (2tailed) atau P-value rata-rata trading volume activity setelah sebesar 0,200 lebih dari 0,05, sehingga dapat disimpulkan data rata-rata trading volume activity semua periode 
pengamatan terdistribusi secara normal.

\section{Hipotesis Ketiga}

Pengujian hipotesis ini dilakukan untuk mengetahui ada atau tidaknya perbedaan antara rata-rata trading volume activity 5 hari sebelum dan rata-rata trading volume activity 5 hari sesudah pengumuman paket kebijakan ekonomi XVI pada saham sektor pertambangan yang terdaftar di Bursa Efek Indonesia tahun 2018 yang ditunjukkan pada tabel 7.

Berdasarkan tabel 7 , pengujian rata-rata trading volume activity dengan tingkat signifikasi $\alpha=5 \%$ atau 0,05 . Menunjukan nilai P Value Sig. (2-tailed) yaitu 0,075 > 0,05 sehingga terdapat perbedaan, maka hipotesis ketiga ditolak yang berarti terdapat perbedaan rata-rata trading volume activity 5 hari sebelum dan 5 hari sesudah pengumuman paket kebijakan ekonomi XVI pada saham sektor pertambangan yang terdaftar di Bursa Efek Indonesia tahun 2018.

\section{Hipotesis Keempat}

Pengujian hipotesis ini dilakukan untuk mengetahui ada atau tidaknya perbedaan antara rata-rata trading volume activity 10 hari sebelum dan rata-rata trading volume activity 10 hari sesudah pengumuman paket kebijakan ekonomi XVI pada saham sektor pertambangan yang terdaftar di Bursa Efek Indonesia tahun 2018 yang ditunjukkan pada tabel 8 .

Berdasarkan tabel 8, pengujian rata-rata trading volume activity dengan tingkat signifikasi $\alpha=5 \%$ atau 0,05 . Menunjukan nilai P Value Sig. (2-tailed) yaitu 0,001 < 0,05 sehingga terdapat perbedaan, maka hipotesis empat diterima yang berarti terdapat perbedaan rata-rata trading volume activity 10 hari sebelum dan 10 hari sesudah pengumuman paket kebijakan ekonomi XVI pada saham sektor pertambangan yang terdaftar di Bursa Efek Indonesia tahun 2018.

\section{Pembahasan Hasil Penelitian}

Pembahasan Hipotesis Pertama dan Kedua

Hasil pengujian pada hipotesis pertama menunjukan tidak terdapat perbedaan ratarata abnormal return. Hasil penelitian ini mendukung hasil penelitian sebelumnya yang dilakukan oleh Edam et al (2017) dan Maharani et al (2018) yang menyatakan bahwa tidak terdapat perbedaan AAR sebelum dan sesudah terjadinya peristiwa. Hasil ini membuktikan bahwa informasi mengenai pengumuman paket kebijakan ekonomi XVI tidak mempengaruhi aktivitas transaksi khususnya pada harga saham, sehingga tidak ada investor yang bisa memanfaatkan return berlebihan. Meskipun isi pengumuman paket kebijakan ekonomi XVI dapat memberikan keuntungan bagi perusahaan lewat tax holiday, tetapi investor sepertinya masih menunggu dan melihat implementasi jangka panjang dari kebijakan ini. Rata-rata abnormal return selama periode pengamatan menunjukan hasil yang positif dan negatif, informasi mengenai tujuan paket kebijakan pada awalnya direspon positif oleh pasar, dapat dilihat dari pergerakan rata-rata abnormal return 1 hari setelah pengumuman paket kebijakan yang meningkat dibandingkan 1 hari sebelum paket kebijakan diumumkan hal ini terjadi karena tujuan paket kebijakan yang dapat memperbaiki nilai perusahaan dan mampu membawa pasar modal kearah yang lebih baik. Antusiasme positif tersebut tidak berlanjut pada 4 hari setelah pengumuman yang mengakibatkan pergerakan rata-rata abnormal return bernilai lebih rendah, penyebab terjadinya rata-rata abnormal return negatif setelah pengumuman dianggap berita negatif, karena disampaikan bahwa perluasan pengurangan pajak penghasilan badan diberlakukan seminggu setelah kebijakan diumumkan, melihat kondisi tersebut dapat dikatakan bahwa investor menanti penerapan kebijakan tersebut. 


\section{Pembahasan Hipotesis Ketiga dan Keempat}

Hasil pengujian pada hipotesis ketiga menunjukan bahwa tidak terdapat rata-rata trading volume activity. Hasil penelitian ini mendukung hasil penelitian sebelumnya yang dilakukan Maharani et al (2018) yang menyatakan bahwa terdapat perbedaan trading volume activity sebelum dan sesudah terjadinya peristiwa. Hasil ini membuktikan bahwa informasi yang diteliti pada peristiwa pengumuman paket kebijakan ekonomi XVI mempengaruhi aktivitas perdagangan khususnya pada volume perdagangan. Pergerakan rata-rata trading volume activity selama periode pengamatan mengalami fluktuasi, $\mathrm{H}+2$ hingga $\mathrm{H}+3$ pergerakan kearah positif tetapi pada $\mathrm{H}+4$ pergerakan trading volume activity mengalami penurunan. Berkaitan dengan abnormal return, tentunya investor masih menunggu dan melihat implementasi jangka panjang dari kebijakan ini. Jika tidak ada investor yang bisa memanfaatkan return berlebih tentu tidak terjadi aksi jual beli saham yang lebih aktif karena investor tidak mengambil keputusan untuk melakukan pembelian saham yang berdampak pada volume perdagangan saham.

Hasil pengujian pada hipotesis keempat menunjukan bahwa terdapat rata-rata trading volume activity 10 hari sebelum dan 10 hari sesudah pengumuman paket kebijakan. Hasil penelitian ini mendukung hasil penelitian sebelumnya yang dilakukan Ariyanto (2016) yang menyatakan bahwa terdapat perbedaan trading volume activity sebelum dan sesudah terjadinya peristiwa. Hasil ini membuktikan bahwa informasi yang diteliti pada peristiwa pengumuman paket kebijakan ekonomi XVI mempengaruhi aktivitas perdagangan khususnya pada volume perdagangan. Pergerakan rata-rata trading volume activity berbeda dengan rata-rata abnormal return, rata-rata trading volume activity bergerak kearah positif baik sebelum maupun sesudah peristiwa, namun peningkatan lebih besar rata-rata trading volume activity terjadi sesudah peristiwa pengumuman paket kebijakan ekonomi XVI pada periode $\mathrm{T}+9$. Kemungkinan, hal ini terjadi karena isi dari paket kebijakan tersebut sudah mulai diterapkan sehingga antusiasme investor dalam melakukan aktivitas jual beli meningkat, yang terlihat meningkatnya jumlah transaksi volume perdagangan. Pemberian fasilitas tax holiday yang diperluas pada sektor pertambangan memberikan manfaat untuk perusahaan, dengan adanya perluasan tersebut perusahaan yang termasuk dalam sektor pertambangan dapat berkembang menjadi lebih baik dan memperkaya pemegang saham atau investor sehingga investor semakin berminat untuk berinvestasi.

Pengujian efesiensi pasar dalam penelitian ini yakni berbentuk efisiensi setengah kuat, karena informasi pengumuman paket kebijakan ekonomi XVI didistribusikan dengan cepat dan menyebar maka semua orang yang ada di pasar modal mendapatkan informasi tersebut. Sehingga tidak ada investor yang mendapatkan abnormal return, karena apabila pelaku pasar mendapatkan abnormal return maka pasar modal Indonesia belum menunjukan pasar yang berbentuk setengah kuat secara informasi.

\section{KESIMPULAN DAN SARAN}

\section{Kesimpulan}

Berdasarkan hasil penelitian dan pembahasan yang telah disampaikan, maka dapat disimpulkan bahwa tidak terdapat perbedaan pada rata-rata abnormal return 5 hari sebelum dan 5 hari sesudah pengumuman paket kebijakan ekonomi XVI terhadap saham sektor pertambangan yang terdaftar di Bursa Efek Indonesia tahun 2018. Hasil analisis juga menunjukkan bahwa tidak terdapat perbedaan 
pada rata-rata abnormal return 10 hari sebelum dan 10 hari sesudah pengumuman paket kebijakan ekonomi XVI terhadap saham sektor pertambangan yang terdaftar di Bursa Efek Indonesia tahun 2018; tidak terdapat perbedaan pada rata-rata trading volume activity 5 hari sebelum dan 5 hari sesudah pengumuman paket kebijakan ekonomi XVI terhadap saham sektor pertambangan yang terdaftar di Bursa Efek Indonesia tahun 2018. Meskipun demikian terdapat perbedaan pada rata-rata trading volume activity 10 hari sebelum dan 10 hari sesudah pengumuman paket kebijakan ekonomi XVI terhadap saham sektor pertambangan yang terdaftar di Bursa Efek Indonesia tahun 2018.

\section{Saran}

Dari penelitian yang telah dilakukan tersebut sampaikan dari hasil penelitian terhadap perusahaan disarankan untuk memanfaatkan pengurangan pajak penghasilan badan atau tax holiday yang terdapat dalam paket kebijakan ekonomi XVI, dengan adanya pemberian tax holiday perusahaan dapat meningkatkan nilai perusahaan yang juga akan memperkaya pemegang saham sehingga investor semakin berminat dalam berinvestasi. Selain itu Investor perlu untuk tetap memperhatikan setiap peristiwa yang berhubungan dengan kebijakan politik dan ekonomi karena dapat memberikan dampak dalam berinvestasi seperti risiko kerugian. Meskipun demikian penelitianini tetap memiliki beberapa kelemahan yaitu tingkat generalisasi terhadap sector yang berbeda akan memiliki hasil yang berbeda pula, terlebih dengan adanya faktor-faktor yang tidak termasuk dalam penelitian ini seperti, sentiment pasar dan kebijakan-kebijakan pertambangan yang dapat mempengaruhi produktifitas pertambangan yang berimbas pada minat kinerja emitten.

\section{DAFTAR PUSTAKA}

Alasan Pemerintah Luncurkan Paket. (2018, November 17). Maret 23, 2019. https://www.suara.com/bisnis/2018/11/1 7/010100/ini-alasan-pemerintahluncurkan-paket-kebijakan-ekonomijilid-16

Ariyani, Vivi (2017). Pengujian efesiensi pasar setengah kuat terhadap pengumuman paket kebijakan ekonomi VII pada saham indeks LQ 45. Jurnal ekonomi Universitas Kadiri.

Ariyanto, Muhammad Falih. (2016). Abnormal return dan trading volume activity saham-saham LQ-45 pada peristiwa pengumuman kebijakan quantitative easing oleh bank sentral Amerika Serikat. Jurnal perbendaharaan, keuangan negara, dan kebijakan publik.

Dayanti, Tisna. (2015). Analisis Perbedaan Abnormal Return Dan Trading Volume Activity Sebelum Dan Sesudah Peristiwa Pengumuman Paket Kebijakan Ekonomi Jilid I Jokowi 2015. Skripsi. Universitas Lambung Mangkurat.

Dewi, Gusti Ayu Surya Rosita, dkk (2017). Reaksi pasar atas pengumuman paket kebijakan ekonomi $\mathrm{X}$ tentang daftar negatif investasi. Jurnal ilmiah akuntansi dan bisnis.

Hartono, J. (2017). Teori Portofolio dan Analisis Investasi Edisi 11. Yogyakarta: BPFE.

(2018). Studi Peristiwa : Menguji Reaksi Pasar Modal Akibat Suatu Peristiwa Edisi Pertama. Yogyakarta : BPFE.

Ikhsan, A. (2014). Metodologi Penelitian Bisnis. Bandung: Citapustaka Media.

Kategori Kebijakan Ekonomi. (2018, November 7). April 10, 2019. https://id.wikipedia.org/wiki/Kategori:K ebijakan_ekonomi.

Kementrian Koordinator Bidang Perekonomian Republik Indonesia (2018, November 16). Paket Kebijakan 
Ekonomi XVI. Maret 22, 2019. https://ekon.go.id/ekliping/view/paketkebijakan-ekonomi-xvi.4446.html.

Maharani, Nandira Adelia (2018). Reaksi pasar modal terhadap pengumuman paket kebijakan ekonomi jilid 1, 5, 7, 11, dan 13. Jurnal riset Akuntansi Kontenporer Vol. 10 No. 2, Oktober 2018. 58-66.

Muzakir, Nurbaity, dkk (2017). Reaksi pasar modal Indonesia terhadap peristiwa pengumuman paket kebijakan ekonomi jilid II. Jurnal Ilmiah Manajemen Vol. 2 No. 2, Mei 2017. 20-34

Pemerintah Umumkan Paket Kebijakan. (2018, November 16). Maret 23, 2019. https://setkab.go.id/pemerintahumumkan-paket-kebijakan-ekonomi-ke$16 /$.
Ringkasan Indeks. (n.d). Mei 12, 2019. https://www.idx.co.id/datapasar/ringkasan-perdagangan/ringkasanindeks/. (2006). Pasar Modal dan Manajemen Portofolio. Jakarta: Penerbit Erlangga.

Sekaran, U. (2017). Metode Penelitian Untuk Bisnis. Jakarta: Salemba Empat.

Tanderlilin, E. (2010). Portofolio dan Investasi Teori dan Aplikasi. Yogyakarta: Kanisius.

Wibowo, Agung (2017). Reaksi investor pasar modal Indonesia terhadap paket kebijakan ekonomi tahap I Jokowi-JK. Media Ekonomi dan Manajemen. 